\title{
Semi-quantitative comparison of the differentiation markers and sodium iodide symporter messenger ribonucleic acids in papillary thyroid carcinomas using RT-PCR
}

\author{
Katsuhiro Tanaka ${ }^{1}$, Takemi Otsuki ${ }^{2}$, Hiroshi Sonoo ${ }^{1}$, Yutaka Yamamoto ${ }^{1}$, Kiyoshi Udagawa ${ }^{1}$, \\ Hironori Kunisue $^{1}$, Ichiro Arime ${ }^{1}$, Shigeru Yamamoto ${ }^{1}$, Junichi Kurebayashi ${ }^{1}$ and Kojiro Shimozuma ${ }^{1}$ \\ Departments of ${ }^{1}$ Breast and Thyroid Surgery and ${ }^{2}$ Hygiene, Kawasaki Medical School, Kurashiki, 701-0192, Japan \\ (Correspondence should be addressed to K Tanaka, Kawasaki Medical School, Department of Breast and Thyroid Surgery, \\ 577 Matsushima, Kurashiki 701-0192, Japan; Email address: tanakaka@med.kawasaki-m.ac.jp)
}

\begin{abstract}
Objective: To investigate the levels of expression of the sodium iodide symporter (NIS) and three differentiation markers (thyroglobulin (Tg), thyroid peroxidase (TPO) and thyrotrophin receptor (TSH-R)) in 35 patients with primary $(n=31)$ or recurrent $(n=4)$ papillary thyroid carcinoma, and to compare the findings with clinical data.

Methods: We performed a multiplex semi-quantitative RT-PCR to analyse the relative levels of expression of Tg, TPO and TSH-R mRNAs, and a separate semi-quantitative RT-PCR for NIS mRNA. Results: Tg, TPO and TSH-R mRNAs were expressed in all the patients, whereas NIS mRNA was expressed in all but eight. Analysis of the expression of the differentiation markers in all patients showed a significant correlation among Tg, TPO and NIS. With regard to the relationship between the expression of each gene and the MACIS score, there was significant correlation only for the $\mathrm{Tg}$ gene $(P<0.05)$.

Conclusions: The levels of expression of NIS mRNA correlated significantly with those of Tg and TPO mRNAs, but not with those of TSH-R mRNA. The relationship with clinical stage and prognostic score, however, varied among these differentiation markers.
\end{abstract}

European Journal of Endocrinology 142 340-346

\section{Introduction}

Thyroid-specific proteins such as thyroglobulin $(\mathrm{Tg})$, thyroid peroxidase (TPO) and thyrotrophin receptor (TSH-R), are regarded as differentiation markers of thyroid follicular cells (1). When serum iodide is taken into thyrocytes, a sodium iodide symporter (NIS) is necessary (2). Because of this phenomenon, NIS also is regarded as a differentiation marker that reflects the production of thyroid hormone. The differentiation markers (Tg, TPO and TSH-R) are also expressed in differentiated thyroid carcinomas (3-5), which have been reported to have the ability to uptake iodide (6). As a result, radioiodine therapy has come into common use in the treatment of recurrent or metastatic differentiated thyroid carcinomas (6-8). Although the effect of this treatment can usually be predicted by using a tracer dose of isotopic iodide (9), a discrepancy in accumulation has often been reported between the tracer and treatment doses in metastatic lesions $(10,11)$. Some studies have reported the successful prediction of the clinical effect of radioiodine therapy or the presence of recurrent sites by measuring serum thyroglobulin in patients who had undergone total thyroidectomy $(9,11,12)$. However, the histological expression of other differentiation markers (Tg, thyroxine and tri-iodothyronine) in tumours has not proved to predict radioiodine uptake successfully (13).

The sequence of human NIS messenger ribonucleic acid (NIS mRNA) was reported in 1996 (14). Since this cloning of NIS mRNA, studies of the expression of NIS mRNA or protein have been undertaken. A more recent study found the protein and mRNA levels of NIS in papillary thyroid carcinomas to be greater than those in adjacent normal thyroid tissues (15). However, varied expression of NIS, including no expression, has also been noted in papillary carcinomas (16-19). In the present study, we investigated the levels of expression of NIS and three other differentiation markers in papillary thyroid carcinomas and compared them with clinical findings.

\section{Patients and methods}

\section{Patients}

We studied 35 patients (31 with primary papillary carcinoma and four with recurrent papillary carcinoma), 
all of whom gave their informed consent to inclusion in the study. All the participants were euthyroid before operation, and none was taking any drugs before operation. All the patients with papillary carcinoma underwent TSH suppression therapy with a thyroxine drug after surgery. The serum TSH values of all four patients with recurrent papillary thyroid carcinoma were below the limit of detection $(<0.05 \mathrm{mU} / \mathrm{l})$. The recurrent sites were the cervical lymph nodes in all these four patients; and dissection of these lymph nodes was performed in all of them. For PCR controls, we used three snap-frozen tissues of normal adjacent thyroid obtained during operation from the patients with papillary carcinoma. The clinical stages of the primary carcinomas were determined according to the International Union against Cancer (UICC) classification (20), and their MACIS scores were calculated according to the protocol of Hay et al. (21).

\section{RT-PCR}

Total cellular RNA was extracted from microdissected snap-frozen tissues using the phenol-guanidineisothiocyanate method with Trizol (Gibco BRL, Gaithersburg, MD, USA) according to the manufacturer's protocol. The purity of the total RNA was assessed by the ratio of optical density $260 \mathrm{~nm}$ to $280 \mathrm{~nm}$ (acceptable values being between 1.6 and 1.9) and by the absence of bands corresponding to contaminating DNA in agarose electrophoresis (data not shown). One microgram total RNA and 20 pmol oligo dT primer in $12.5 \mu \mathrm{l}$ diethyl pirocarbonate (DEPC)treated water were heated to $70^{\circ} \mathrm{C}$ for $2 \mathrm{~min}$, followed by cooling on ice for $1 \mathrm{~min}$. cDNA synthesis was initiated using $200 \mathrm{U}$ recombinant Moloney-murine leukaemia virus reverse transcriptase (Clontech Lab. Inc., Palo Alto, CA, USA) under conditions recommended by the manufacturer, and the reaction was allowed to proceed at $42{ }^{\circ} \mathrm{C}$ for $60 \mathrm{~min}$, when it was terminated by heating at $94^{\circ} \mathrm{C}$ for $5 \mathrm{~min}$ and the cDNA diluted to a final volume of $100 \mu \mathrm{l}$ by adding $80 \mu \mathrm{l}$ DEPC-treated water. The oligonucleotide primers, including $\beta$-actin cDNA (22), and the conditions for amplification of Tg cDNA (23), TPO cDNA (24), TSH-R cDNA (25) and NIS cDNA (14) are shown in Table 1 and Fig. 1a. The primers were made from cDNA sequences. Three oligonucleotide primers of each gene except $\beta$-actin were made and we selected one primer set from each without interfering with the $\beta$-actin primer set (data not shown). The PCR was performed using a PC-960G microplate gradient thermal cycler (Corbett Research, Mortlake, Australia). Each RT-PCR reaction comprised $2 \%$ of cDNA (equivalent to the amount of cDNA obtained from $20 \mathrm{ng}$ initial total RNA), $200 \mathrm{nmol} / \mathrm{l}$ concentrations of each primer, $200 \mu \mathrm{mol} / \mathrm{l}$ deoxynucleotide triphosphate, $10 \mathrm{mmol} / \mathrm{l}$ Tris $-\mathrm{HCl}$ ( $\mathrm{pH} 8.8$ ), each concentration of $\mathrm{MgCl}_{2}$ shown in Table 1, $50 \mathrm{mmol} / \mathrm{l} \mathrm{KCl,} 0.08 \%$ Nonident p40 and $1 \mathrm{U}$

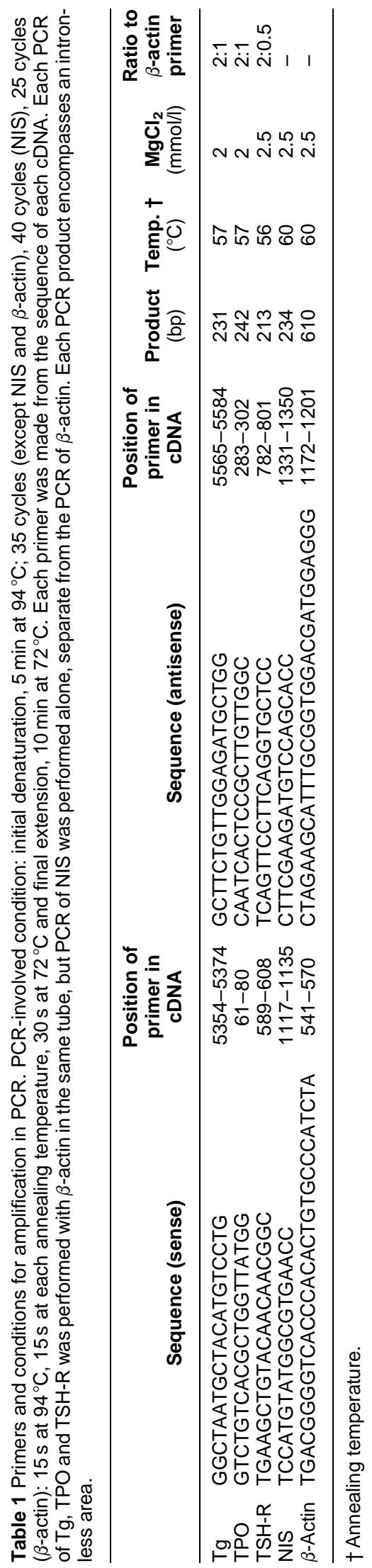


$\{a \mid$

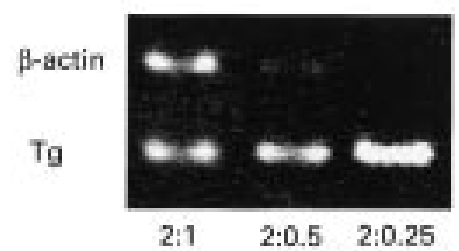

[b]
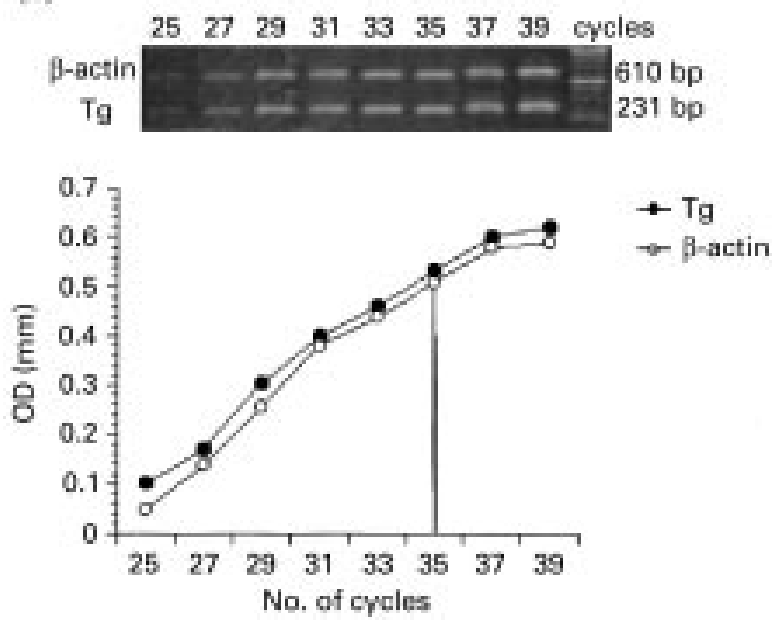

Figure 1 (a) Selection of the ratio of each primer (Tg, TPO and TSH-R) and $\beta$-actin primer for multiplex RT-PCR, showing the three different ratios of $\mathrm{Tg}$ and $\beta$-actin primer in the same tube. In this case, we selected a ratio of $2: 1$. (b) Selection of the thermocycle of each primer for multiplex RT-PCR, showing the semiquantification of Tg mRNA and $\beta$-actin in serial thermocycles (25-39 cycles). Logarithmic 35 thermocycles of the amplification was selected for Tg multiplex RT-PCR. The conditions of multiplex PCR using other primers were decided by the same methods.

recombinant Thermus aquaticus DNA polymerase (MBI Fermentas, Vilnius, Lithuania) in a final volume of $20 \mu$ l.

A semi-quantitative multiplex RT-PCR in the same tube was designed to compare the RT-PCR products of the Tg, TPO and TSH-R genes with $\beta$-actin gene products to determine the relative levels of expression of the Tg, TPO and TSH-R mRNAs in these patients. To obtain a phase in which both the differentiation marker mRNAs and the $\beta$-actin mRNA would be amplified logarithmically (Fig. $1 b$ ), each reaction of a semi-quantitative multiplex RT-PCR contained the same reagents described above, except for the addition of each primer with the primer of $\beta$-actin (Table 1 ). We attempted to perform a semi-quantitative multiplex RT-PCR in the same tube, to detect the NIS mRNA, but we could not obtain reproducible results, and therefore we used a separate RT-PCR for the NIS and the $\beta$-actin mRNA (Table 1). To determine the specificity of these RT-PCRs, we performed them three times and took the mean values of the three replications. Each RT-PCR product was demonstrated on $1.4 \%$ agarose gel stained with ethidium bromide. The bands of the positive film were scanned and the density and the width of each PCR product were measured using Quantity One software (pdi, New York, NY, USA) to calculate the ratio of each product of the Tg, TPO, TSH-R and NIS mRNAs to $\beta$-actin mRNA. We used adjacent normal thyroid tissues as positive controls. We also performed a PCR without cDNA, using each primer as a negative control. One negative control and three positive controls were included in every reaction. In addition, we evaluated the relationship between the relative rates in each patient and their clinical characteristics.

\section{Statistical analysis}

For statistical analysis, Mann-Whitney's $U$ test and the Scheffé test were used as post hoc tests; Welch's $t$-test and Pearson's correlation coefficient test were also used. $P<0.05$ was taken as significant.

\section{Results}

\section{Clinical characteristics (Table 2)}

Twenty-six $(74.3 \%)$ of the 35 patients were women and nine $(25.7 \%)$ were men. The mean age of the patients with primary papillary carcinoma was 52.26 years (range 20-74 years) and that of the patients with recurrent disease was 75 years $(58-90$ years). Six patients with primary papillary carcinoma showed extrathyroidal infiltration. There were 10 patients with stage 1 , three patients with stage 2 and 18 patients with stage 3 carcinoma. The mean \pm S.D. tumour size and MACIS score were $2.53 \pm 1.7 \mathrm{~cm}$ and $5.32 \pm 1.2$ respectively.

\section{Levels of expression of Tg, TPO, TSH-R and NIS MRNA}

The three differentiation markers, Tg, TPO, TSH-R mRNAs, were expressed in all patients. NIS mRNA was not expressed in eight of them (nos 12, 20, 24, 26, 28, 31,32 and 33); Fig. 2 shows the findings in two of them (nos 26 and 28). In the patients with primary papillary carcinoma, the mean \pm S.D. values of the ratio relative to the $\beta$-actin gene were $1.7 \pm 0.84(\mathrm{Tg})$, $0.46 \pm 0.19$ (TPO), $1.31 \pm 1.53$ (TSH-R) and 3.37 \pm 1.76 (NIS). In the patients with recurrent papillary carcinoma, the ratios were $1.7 \pm 1.56,0.65 \pm 0.30$, $0.71 \pm 0.40$ and $3.25 \pm 1.82$ respectively. The ratios of each product of the Tg, TPO, TSH-R and NIS mRNAs to $\beta$-actin mRNA in primary papillary thyroid carcinoma are shown in Fig. 3. In all the patients, there was a positive correlation among the differentiation markers, Tg, TPO and NIS with respect to levels of expression (Fig. 4). 
Table 2 The clinical characteristics of the patients. MACIS score was determined according to Hay's protocol (21), and was defined as 3.1 (if patient aged $\leqq 39$ years) or $0.08 \times$ age (if patient aged $>40$ years); $+0.3 \times$ tumour size (in $\mathrm{cm}$ ), +1 (if incompletely resected), +1 (if locally invasive) or +3 (if distant metastases). Stage was decided according to the UICC classification.

\begin{tabular}{|c|c|c|c|c|c|c|c|}
\hline & $\begin{array}{c}\text { Patient } \\
\text { no. }\end{array}$ & $\begin{array}{c}\text { Age } \\
(\mathrm{yr})\end{array}$ & Sex & Invaded organ & Size $(\mathrm{cm})$ & Stage & MACIS score \\
\hline \multicolumn{8}{|l|}{ Primary PTC } \\
\hline & 1 & 62 & M & Trachea & 2 & III & 6.56 \\
\hline & 2 & 63 & $\mathrm{~F}$ & Trachea & 1.8 & III & 6.58 \\
\hline & 3 & 49 & $\mathrm{~F}$ & - & 1 & 1 & 4.22 \\
\hline & 4 & 63 & $\mathrm{~F}$ & - & 3 & III & 5.64 \\
\hline & 5 & 48 & $\mathrm{M}$ & - & 8.5 & III & 6.39 \\
\hline & 6 & 24 & $\mathrm{~F}$ & - & 2.5 & 1 & 3.85 \\
\hline & 7 & 30 & $\mathrm{~F}$ & - & 3.5 & I & 4.15 \\
\hline & 8 & 20 & $\mathrm{~F}$ & - & 2 & I & 3.7 \\
\hline & 9 & 74 & $\mathrm{~F}$ & Trachea, oesophagus & 5 & III & 8.42 \\
\hline & 10 & 42 & M & - & 3.5 & 1 & 4.06 \\
\hline & 11 & 31 & $\mathrm{~F}$ & Recurrent nerve & 2 & I & 5.7 \\
\hline & 12 & 53 & M & - & 2.4 & III & 4.96 \\
\hline & 13 & 45 & $\mathrm{~F}$ & - & 2.2 & III & 4.26 \\
\hline & 14 & 51 & $\mathrm{~F}$ & - & 1.4 & III & 4.52 \\
\hline & 15 & 61 & $\mathrm{~F}$ & - & 2.5 & III & 5.63 \\
\hline & 16 & 73 & $\mathrm{~F}$ & - & 3.5 & III & 6.54 \\
\hline & 17 & 48 & $\mathrm{~F}$ & - & 2.5 & ॥ & 4.59 \\
\hline & 18 & 56 & M & _- & 7 & III & 6.58 \\
\hline & 19 & 55 & $\mathrm{~F}$ & - & 1.2 & II & 4.76 \\
\hline & 20 & 67 & $\mathrm{~F}$ & - & 2 & II & 5.97 \\
\hline & 21 & 59 & $\mathrm{~F}$ & - & 1.8 & III & 5.08 \\
\hline & 22 & 53 & $\mathrm{~F}$ & Trachea & 2.5 & III & 6.99 \\
\hline & 23 & 56 & $\mathrm{~F}$ & - & 2.2 & III & 5.14 \\
\hline & 24 & 39 & $\mathrm{~F}$ & - & 2.4 & I & 3.82 \\
\hline & 25 & 60 & $\mathrm{~F}$ & - & 1.2 & III & 5.16 \\
\hline & 26 & 64 & $\mathrm{~F}$ & Recurrent nerve & 1.2 & III & 7.48 \\
\hline & 27 & 69 & $\mathrm{~F}$ & - & 0.9 & 1 & 5.73 \\
\hline & 28 & 36 & $\mathrm{~F}$ & - & 1.5 & I & 3.55 \\
\hline & 29 & 58 & $\mathrm{~F}$ & - & 2.5 & III & 5.39 \\
\hline & 30 & 51 & $M$ & - & 1.8 & III & 4.44 \\
\hline & 31 & 60 & $\mathrm{~F}$ & - & 1 & 1 & 5.1 \\
\hline Mean \pm S.D. & & $52.26 \pm 13.7$ & & & $2.53 \pm 1.7$ & & $5.32 \pm 1.2$ \\
\hline \multicolumn{8}{|c|}{ Recurrent PTC } \\
\hline & 32 & 65 & M & - & - & - & \\
\hline & 33 & 58 & M & - & - & - & \\
\hline & 34 & 90 & $\mathrm{~F}$ & - & - & - & \\
\hline & 35 & 85 & M & - & - & - & \\
\hline Mean \pm S.D. & & $75 \pm 15$ & & & & & \\
\hline
\end{tabular}

PTC, papillary thyroid carcinoma.

\section{Relationship between the expression of differentiation markers and clinical characteristics in patients with primary papillary carcinoma (Table 3)}

In the patients with primary papillary carcinoma, there was a significant correlation between the expression of each mRNA and the MACIS score only for the $\mathrm{Tg}$ gene $(P<0.05)$. There were no significant differences between other clinical data, including age, sex, tumour size and extrathyroidal invasion, and the levels of expression of the four differentiation markers.

\section{Discussion}

All the participants in this study expressed three differentiation markers, Tg, TPO and TSH-R. Among those with either primary or recurrent papillary carcinoma, eight did not express NIS mRNA. In a recent report, Arturi et al. observed a reduction in the NIS gene in papillary carcinoma (16), whereas Saito et al. (15) reported that expression of the NIS gene was greater in papillary carcinomas than in adjacent normal thyroid tissues. However, clinically, the ability of normal thyrocytes to take up radioiodide is considered to be much greater than that of papillary thyroid 


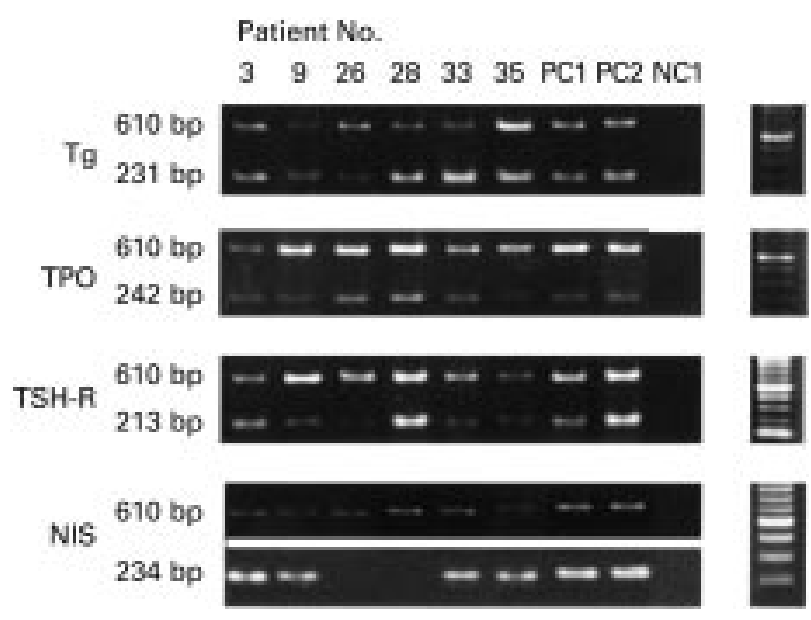

Figure 2 Results of PCR. A semi-quantitative multiplex RT-PCR in the same tube was designed to compare the RT-PCR products of the $\mathrm{Tg}, \mathrm{TPO}$ and TSH-R genes with $\beta$-actin gene products, to determine the relative levels of expression of the these genes. We used separate RT-PCRs for the NIS and the $\beta$-actin genes (Table 1). Each RT-PCR product was demonstrated on 1.2\% agarose gel stained by ethidium bromide. The inverted image of actual electrophoresis was displayed. The results demonstrate four cases of primary papillary thyroid carcinoma (patients nos 3 , 9,26 and 28) and two cases of recurrent papillary thyroid carcinoma (patients nos 33 and 35). Lanes PC1 and PC2: positive controls using adjacent normal thyroid tissue. Lane NC1: negative controls (no cDNA).

carcinoma tissue (26); our findings, and those of Arturi et al. (16), seem to be in accordance with this clinical ability. Other investigators have reported the reduction in expression of the NIS gene to be dependent on $\mathrm{Tg}$ (27), transforming growth factor $\beta 1(28,29)$ and tumour necrosis factor (28); TSH, in contrast, stimulates the expression of the NIS mRNA $(30,31)$. Our results showed ageing to be unrelated to a reduction in expression of the NIS gene. Other investigators have

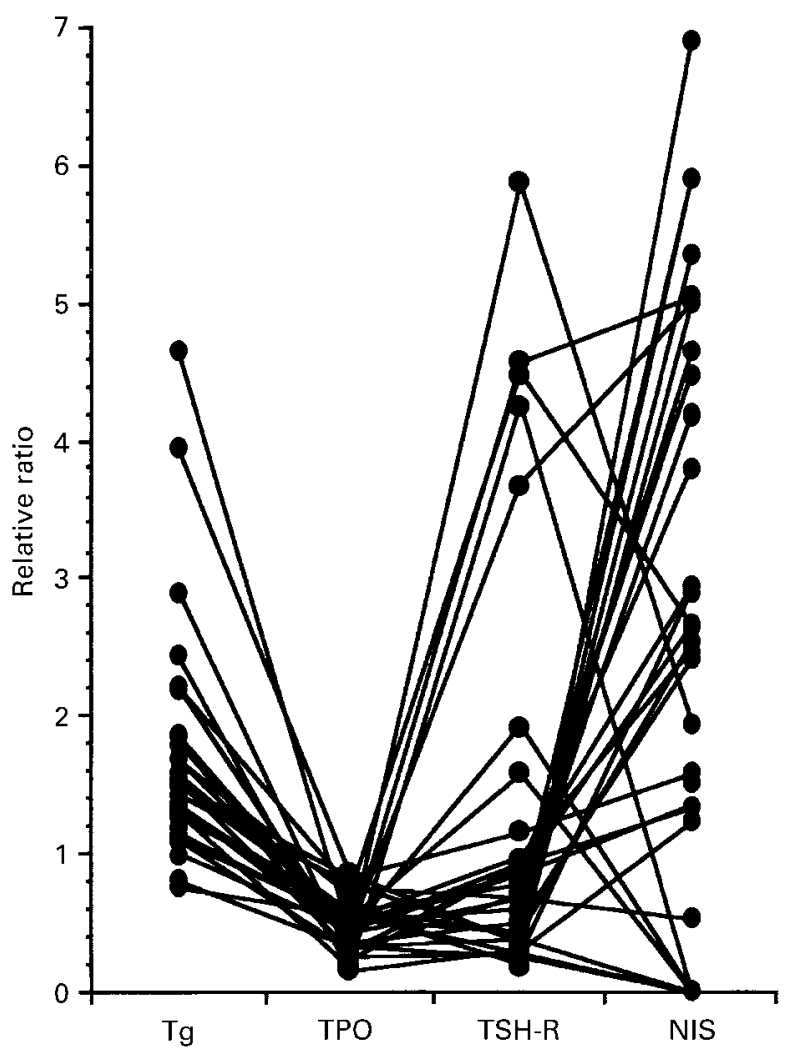

Figure 3 The level of expression of each marker in primary papillary carcinoma, normalized as the ratio relative to the amount of $\beta$-actin. The bands of the positive film were scanned and the density and the width of each PCR product were measured using the software package, Quantity One $(p d l)$. The value of each band was represented as $\mathrm{OD} \times \mathrm{mm}$. We calculated the ratio of each product of the Tg, TPO, TSH-R and NIS mRNAs to $\beta$-actin mRNA. In the patients with primary carcinoma, the mean \pm S.D. values of the relative ratio of each PCR product to $\beta$-actin were $1.7 \pm 0.84(\mathrm{Tg}), 0.46 \pm 0.19$ (TPO), $1.31 \pm 1.53$ (TSH-R) and $3.37 \pm 1.76$ (NIS) respectively.

Table 3 Relationship between the expression of differentiation markers (normalized as the ratio relative to the amount of $\beta$-actin) and clinical characteristics of patients with primary papillary thyroid carcinoma. Results are means \pm S.D.

\begin{tabular}{|c|c|c|c|c|c|c|c|c|}
\hline & \multicolumn{8}{|c|}{ Correlations } \\
\hline & $\mathrm{Tg}$ & & TPO & & TSH-R & & NIS & \\
\hline $\begin{array}{l}\text { MACIS* }^{*} \\
\text { Age }^{*}\end{array}$ & $\begin{array}{l}P=0.030 \\
P=0.265\end{array}$ & $r=0.388$ & $\begin{array}{l}P=0.573 \\
P=0.237\end{array}$ & & $\begin{array}{l}P=0.847 \\
P=0.155\end{array}$ & & $\begin{array}{l}P=0.814 \\
P=0.869\end{array}$ & \\
\hline $\begin{array}{l}\text { Sext } \\
\quad \text { Male }(n=9) \\
\quad \text { Female }(n=26)\end{array}$ & $\begin{array}{l}1.73 \pm 1.1 \\
1.73 \pm 0.8\end{array}$ & $P=1.00$ & $\begin{array}{l}0.56 \pm 0.2 \\
0.43 \pm 0.2\end{array}$ & $P=0.10$ & $\begin{array}{l}1.58 \pm 2.1 \\
1.25 \pm 1.4\end{array}$ & $P=0.60$ & $\begin{array}{l}2.09 \pm 1.7 \\
2.87 \pm 2.2\end{array}$ & $\ddagger_{P}=0.34$ \\
\hline Tumor size* & $P=0.100$ & & $P=0.817$ & & $P=0.710$ & & $P=0.589$ & \\
\hline $\begin{array}{l}\text { Extrathyroidal invasion } \dagger \\
\quad+(n=6) \\
\quad-(n=29)\end{array}$ & $\begin{array}{l}2.53 \pm 1.5 \\
1.54 \pm 0.5\end{array}$ & $P=0.17$ & $\begin{array}{l}0.54 \pm 0.2 \\
0.44 \pm 0.2\end{array}$ & $P=0.27$ & $\begin{array}{l}0.92 \pm 0.5 \\
1.41 \pm 1.7\end{array}$ & $P=0.20$ & $\begin{array}{l}3.28 \pm 2.3 \\
3.23 \pm 1.8\end{array}$ & $\S_{P}=0.95$ \\
\hline
\end{tabular}

* Analysed by Pearson's method; † analysed by Welch's $t$-test.

$\ddagger$ Analysed between male and female.

$\S$ Analysed between + and - . 

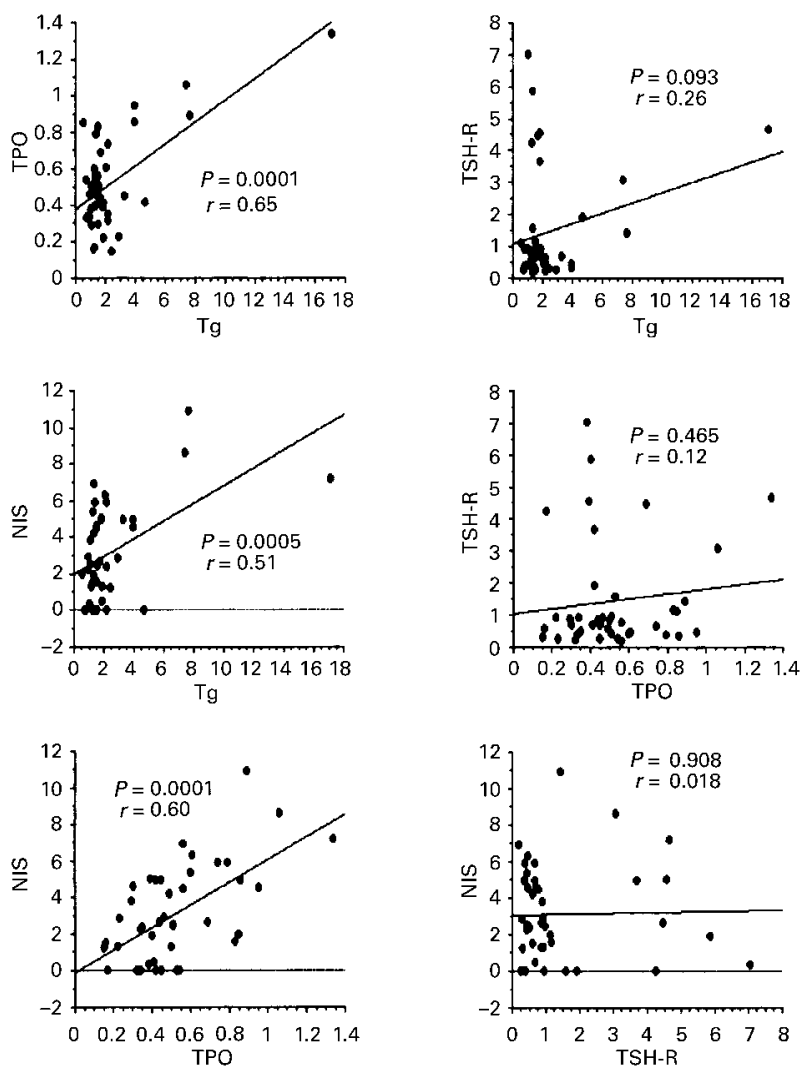

Figure 4 Correlations among the differentiation markers. The ratio of each product of the Tg, TPO, TSH-R and NIS mRNAs to $\beta$-actin mRNA in all patients is shown in Fig. 3 . There was positive correlation among Tg, TPO and NIS with respect to the relationship of the expression of these differentiation markers in all the patients.

reported variations in the expression of $\mathrm{Tg}$ or TPO, from normal to their absence $(3,5)$. In all the participants in the present study, there were significantly positive correlations of the Tg, TPO and NIS mRNAs with each other, but expression of the TSH-R gene did not correlate with the other differentiation markers. Edmonds \& Kermode (32) reported that in vivo measurement of TSH-R in tumours is unlikely to be useful in predicting the concentration of radioiodine to the targeted tumour (32). Saito et al. (15) also reported that there was no significant correlation between TSH-R and Tg, TPO, or NIS mRNA. Some investigators have also reported different regulation and expression of the $\mathrm{Tg}$, TPO and TSH-R genes $(5,33)$; others, however, have reported a positive correlation between $\mathrm{Tg}$ and TSH-R mRNA (3). Clinically, a greater serum Tg value is regarded as a good predictor of the effect of isotopic iodide therapy in most cases of papillary carcinoma (34).

In our previous studies $(35,36)$, we reported that, in papillary carcinomas, those patients who showed heterogeneous distribution of TSH-R mRNA tended to be in advanced stages of the diseases. A significantly poorer prognostic score was also achieved by patients with papillary carcinomas having a weaker intensity of TSH-R protein than that of the adjacent normal thyroid. In this study, we investigated the correlation of these differentiation markers, including the NIS gene, and the relationship between their levels of expression and the clinical findings in patients with papillary carcinoma. As noted in our previous study (35), expression of the TSH-R gene in the advanced stages of the disease was significantly lower than that in the early stages. However, in the correlation between the MACIS score and each gene, only Tg showed a significant correlation. Other investigators have reported a reduction in the differentiation markers in cases of papillary carcinoma with a high potential for malignancy $(3,37)$. On the basis of our findings, with the exception of TSH-R mRNA, the NIS mRNA level significantly correlated with Tg and with TPO as classical differentiation markers of each other. However, the relationships with clinical stage and prognostic score varied among these differentiation markers.

\section{References}

1 Taurog A. Hormone synthesis: thyroid iodine metabolism. In Werner and Ingbar's The Thyroid, edn 6, pp. 54-59. Eds LE Braverman \& RD Utiger. Philadelphia: JB Lippincott Company, 1991.

2 Eskandari S, Loo DDF, Dai G, Levy O, Wright EM \& Carrasco N. Thyroid $\mathrm{Na}^{+} / \mathrm{I}^{-}$symporter. Journal of Biological Chemistry 1997 272 27230-27238.

3 Ohta K, Endo T \& Onaya T. The mRNA levels of thyrotropin receptor, thyroglobulin and thyroid peroxidase in neoplastic human thyroid tissues. Biochemical and Biophysical Research Communications 1991174 1148-1153.

4 Schlumberger M, Charbord P, Fragu P, Lumbroso J \& Parmentier C. Circulating thyroglobulin and thyroid hormones in patients with metastases of differentiated thyroid carcinoma: relationship to serum thyrotropin levels. Journal of Clinical Endocrinology and Metabolism 1980 51 513-519.

5 Brabant G, Maenhaut C, Köhrle J, Scheumann G, Dralle H, Hoang-Vu $\mathrm{C}$ et al. Human thyrotropin receptor gene: expression in thyroid tumors and correlation to markers of thyroid differentiation and dedifferentiation. Molecular and Cellular Endocrinology 199182 R7-R12.

6 Wollman SH. Analysis of radioiodine therapy of metastatic tumors of the thyroid gland in man. Journal of National Cancer Institution $195313815-828$.

7 Leeper RD. The effect of ${ }^{131}$ I therapy on survival of patients with metastatic papillary or follicular thyroid carcinoma. Journal of Clinical Endocrinology and Metabolism 197336 1143-1152.

8 Krishnamurphy GT \& Blahd WH. Radioiodide I-131 therapy in the management of thyroid cancer. Cancer 197740 195-202.

9 Pineda JD, Lee T, Ain K, Reynolds JC \& Robbins J. Iodide-131 therapy for thyroid cancer patients with elevated thyroglobulin and negative diagnostic scan. Journal of Clinical Endocrinology and Metabolism 199580 1488-1492.

10 Schlumberger M, Arcangioli O, Piekarski JD, Tubiana M \& Parmentier C. Detection and treatment of lung metastases of differentiated thyroid carcinoma in patients with normal chest X-rays. Journal of Nuclear Medicine 198829 1790-1794.

11 Pacini F, Lippi F, Formica N, Elisei R, Anelli S, Ceccarelli C et al. Therapeutic doses of iodide-131 reveal undiagnosed metastases 
in thyroid cancer patients with detectable serum thyroglobulin levels. Journal of Nuclear Medicine 198728 1888-1891.

12 Schlumberger M, Mancusi F, Baudin E \& Pacini F. ${ }^{131}$ I therapy for elevated thyroglobulin levels. Thyroid 19977 273-276.

13 Bätge B, Dralle H, Padberg B, von Herbay B \& Schröder S. Histology and immunocytochemistry of differentiated thyroid carcinomas do not predict radioiodine uptake: a clinicomorphological study of 62 recurrent or metastatic tumours. Virchows Archiv A Pathological Anatomy and Histopathology 1992421 521-526.

14 Smanik PA, Liu Q, Furminger TL, Ryu K, Xing S, Mazzaferri EL et al. Cloning of the human sodium iodide symporter. Biochemical and Biophysical Research Communications 1996226 339-345.

15 Saito T, Endo T, Kawaguchi A, Ikeda M, Katoh R, Kawaoi A et al. Increased expression of the sodium/iodide symporter in papillary thyroid carcinomas. Journal of Clinical Investigation 1998101 $1296-1300$.

16 Arturi F, Russo D, Schlumberger M, du Villard JA, Caillou B, Vigneri $\mathrm{P}$ et al. Iodide symporter gene expression in human thyroid tumors. Journal of Clinical Endocrinology and Metabolism $1998832493-2496$.

17 Smanik PA, Ryu K-Y, Theil KS, Mazzaferri EL \& Jhiang SM. Expression, exon-intron organization, and chromosome mapping of the human sodium iodide symporter. Endocrinology 1997138 $3555-3558$.

18 Schmutzler C, Winzer R, Meissner-Weigl J \& Köhrle J. Retinoic acid increases sodium/iodide symporter mRNA levels in human thyroid cancer cell lines and suppresses expression of functional symporter in nontransformed FRTL-5 rat thyroid cells. Biochemical and Biophysical Research Communications 1997240 $832-838$.

19 Ryu K-Y, Senokozlieff ME, Smanik PA, Wong MG, Siperstein AE, Duh Q-Y et al. Development of reverse transcription-competitive polymerase chain reaction methods to quantitate the expression levels of human sodium iodide symporter. Thyroid 19999 405-409.

20 Sobin LH \& Wittekind C. International Union Against Cancer TNM Classification Of Malignant Tumours, edn 5, pp. 47-50. New York: Wiley-Liss, 1997

21 Hay ID, Bergstralh EJ, Goellner JR, Ebersold JR \& Grant CS. Predicting outcome in papillary thyroid carcinoma: development of a reliable prognostic scoring system in a cohort of 1779 patients surgically treated at one institution during 1940 through 1989. Surgery 1993114 1050-1058.

22 Ponte P, Ng SY, Engel J, Gunning P \& Kedes L. Evolutionary conservation in the untranslated regions of actin mRNAs: DNA sequence of a human beta-actin cDNA. Nucleic Acids Research $1984121687-1696$.

23 Malthiéryiry Y \& Lissitzky S. Primary structure of human thyroglobulin deduced from the sequence of its 8448-base complementary DNA. European Journal of Biochemistry 1987 $165491-498$.

24 Liebert F, Ruel J, Ludgate M, Swillens S, Alexander A, Vassart G et al. Complete nucleotide sequence of the human thyroperoxidase-microsomal antigen cDNA. Nucleic Acids Research 1987156735

25 Nagayama Y, Kaufman KD, Seto P \& Rapoport B. Molecular cloning, sequence and functional expression of the cDNA for the human thyrotropin receptor. Biochemical and Biophysical Research Communications 1989165 1184-1190.

26 Mazzaferri EL. Radioiodine and other treatments and outcomes. In Werner and Ingbar's The Thyroid, edn 6, pp 1151-1154. Eds LE Braverman \& RD Utiger. Philadelphia: JB Lippincott Company, 1991.

27 Suzuki K, Lavaroni S, Mori A, Ohta M, Saito J, Pietrarelli M et al. Autoregulation of thyroid-specific gene transcription by thyroglobulin. Proceedings of the National Academy of Sciences of the USA 199895 8251-8256.

28 Pekary AE, Hershman JM \& Berg L. Tumor necrosis factor, ceramide, transforming growth factor- $\beta 1$, and aging reduce $\mathrm{Na}^{+} / \mathrm{I}^{-}$symporter messenger ribonucleic acid levels in FRTL-5 cells. Endocrinology $1998139703-712$.

29 Kawaguchi A, Ikeda M, Endo T, Kogai T, Miyazaki A \& Onaya T. Transforming growth factor- $\beta 1$ suppresses thyrotropin-induced $\mathrm{Na}^{+} / \mathrm{I}^{-}$symporter messenger RNA and protein levels in FRTL-5 rat thyroid cells. Thyroid 19977 789-794.

30 Kogai T, Endo T, Saito T, Miyazaki A, Kawaguchi A \& Onaya T. Regulation by thyroid-stimulating hormone of sodium/iodide symporter gene expression and protein levels in FRTL-5 cells. Endocrinology 1997138 2227-2232.

31 Saito T, Endo T, Kawaguchi A, Ikeda M, Nakazato M, Kogai T et al. Increased expression of the Na+/I- symporter in cultured human thyroid cells exposed to thyrotropin and in Graves' thyroid tissue. Journal of Clinical Endocrinology and Metabolism 199782 $3331-3336$.

32 Edmonds CJ \& Kermode JC. Thyrotropin receptors, tumour radioiodine concentration and thyroglobulin secretion in differentiated thyroid cancers. British Journal of Cancer 198552 537-541.

33 Pohl V, Maenhaut C, Gérard C, Vassart G \& Dumont JE. Differential regulation of thyrotropin receptor and thyroglobulin mRNA accumulation at the cellular level: an in situ hybridization study. Experimental Cell Research 1992199 392-397.

34 Edmonds CJ, Hayes S, Kermode JC \& Thompson BD. Measurement of serum TSH and thyroid hormones in the management of treatment of thyroid carcinoma with radioiodine. British Journal of Radiology 197750 799-807.

35 Tanaka K, Inoue $\mathrm{H}$, Miki H, Komaki K \& Monden Y. Heterogeneous distribution of thyrotropin receptor messenger ribonucleic acid (TSH-R mRNA) in papillary thyroid carcinomas detected by in situ hybridization. Clinical Endocrinology 199644 $259-267$.

36 Tanaka K, Inoue $\mathrm{H}$, Miki $\mathrm{H}$, Masuda E, Kitaichi M, Komaki K et al. Relationship between prognostic score and thyrotropin receptor (TSH-R) in papillary thyroid carcinoma: immunohistochemical detection of TSH-R. British Journal of Cancer 199776 594-599.

37 Berge-Lefranc JL, Cartouzou G, Micco C, Fragu P \& Lissitzky S. Quantification of thyroglobulin messenger RNA by in situ hybridization in differentiated thyroid cancers. Cancer 198556 345-350.

Received 7 July 1999

Accepted 14 December 1999 